\title{
STRATEGI KOMUNIKASI JAKARTAGOODGUIDE DALAM MENINGKATKAN AWARENESS PUBLIK TERHADAP DAYA TARIK WISATA KOTA TUA, JAKARTA
}

\author{
Renny Hidayat ${ }^{1}$, Jaya Purnawijaya ${ }^{2}$ \\ ${ }^{1,2}$ Sekolah Tinggi Ilmu Komunikasi, London School of Public Relations Jakarta \\ Email: gracia.hidayat@gmail.com ${ }^{1}$, jaya.palibasa@gmail.com ${ }^{2}$
}

\begin{abstract}
Indonesia is one of the tourist destinations to be visited by tourists because it has many attractive tourist attractions. One of the tourist destinations is Jakarta, which has historical heritage buildings in Kota Tua or the Old City. Tourists who visit these objects can learn about the history of Jakarta City. However, not all tourists, especially foreign tourists, understand the historical story of the Old City, so to explain to tourists, tour guide services are needed. In the Old City there is a Tour guide community, namely Jakarta GoodGuide which was established specifically to introduce the Kota Tua of Jakarta. This research aims to analyze the communication strategy used by JakartaGoodGuide to increase public awareness of the tourist attraction of Kota Tua, Jakarta. The research used qualitative method through interview and observation techniques. The results showed that the communication strategy was carried out by JakartaGoodGuide used persuasive communication, casual words, structured communication, and pictures during the walking tour.
\end{abstract}

Keywords: communication strategy, awareness, tourist attraction

\begin{abstract}
Abstrak
Indonesia merupakan salah satu negara yang memiliki banyak daerah tujuan wisata untuk dikunjungi wisatawan, karena memiliki banyak daya tarik wisata yang menarik. Salah satu daerah tujuan wisata tersebut adalah Jakarta yang memiliki daya tarik bangunan peninggalan sejarah di Kota Tua. Wisatawan yang mengunjungi objek tersebut dapat mempelajari sejarah Kota Jakarta. Namun tidak semua wisatawan, khususnya wisatawan mancanegara mengerti jalan cerita sejarah Kota Tua, maka untuk menjelaskan kepada wisatawan tersebut diperlukan jasa tourguide. Di Kota Tua terdapat komunitas tourguide, yaitu JakartaGoodGuide yang didirikan khusus untuk memperkenalkan Kota Tua Jakarta. Tujuan penelitian ini untuk menganalisis tentang strategi komunikasi yang digunakan oleh JakartaGoodGuide untuk meningkatkan awareness publik terhadap daya tarik wisata Kota Tua, Jakarta. Metode penelitian yang digunakan adalah kualitaif melalui teknik wawancara dan pengamatan. Hasil penelitian menunjukkan, strategi komunikasi yang dilakukan JakartaGoodGuide menggunakan komunikasi persuasif, menggunakan kata-kata ringan, komunikasi terstruktur, dan juga menggunakan alat bantu foto atau gambar pada saat walking tour berlangsung.
\end{abstract}

Kata Kunci: strategi komunikasi, awareness, daya tarik wisata.

PENDAHULUAN 
Indonesia merupakan salah satu negara tujuan utama kunjungan wisatawan mancanegara karena objek dan daya tarik wisatanya yang menarik. Hampir seluruh wilayah di Indonesia memiliki daya tarik yang dapat dibanggakan kepada wisatawan yang berkunjung ke Indonesia., diantaranya adalah Bali, Jogjakarta, dan Jakarta. Salah satu daerah tujuan wisata di Jakarta yang mempunyai daya tarik bangunan peninggalan sejarah adalah kawasan Kota Tua.

Di sekitar kawasan Kota Tua terdapat beberapa bangunan kuno peninggalan Belanda beberapa diantaranya dijadikan museum seperti: Museum Fatahillah, Museum Bank Indonesia, Museum Bank Mandiri, Museum Seni Rupa dan Keramik, dan Museum Wayang. Wisatawan yang mengunjungi objek tersebut dapat mempelajari sejarah Kota Jakarta. Namun, tidak semua wisatawan, khususnya wisatawan mancanegara mengerti jalan cerita sejarah Kota Tua tersebut. Oleh karena itu, diperlukan jasa tourguide untuk menjelaskan kepada wisatawan tersebut. Di Kota Tua terdapat komunitas tourguide, JakartaGoodGuide yang didirikan khusus untuk mengenalkan Kota Tua.

JakartaGoodGuide (JGG) merupakan sebuah komunitas tourguide yang didirikan khusus untuk memperkenalkan Kota Jakarta. Komunitas ini terdiri dari beberapa anak muda yang memang ahli di bidang pariwisata. Tidak hanya itu, mereka juga memberikan kesempatan bagi para siswa siswi SMK Pariwisata untuk berlatih berbicara dengan cara membawakan tour setiap minggunya di libur sekolah (JakartaGoodGuide, 2014).

Komunitas ini mulai dikenal banyak orang dari berbagai kalangan umur, yaitu anak kecil hingga orang dewasa. Para peserta JGG, awalnya mengetahui komunitas ini melalui publikasi yang dilakukan oleh anggota komunitas melalui instagram dan twitter. Setelah memiliki banyak peserta, para peserta yang merasa puas dengan apa yang diberikan oleh komunitas ini pun melakukan word of mouth kepada temanteman mereka, sehingga JGG ini semakin dikenal oleh wisatawan domestik maupun mancanegara. Dan juga komunitas ini seringkali membuat paket tour menarik untuk mengenal Kota Jakarta, sehingga publik merasa ingin mencoba untuk ikut serta dalam Jakarta Walking Tour. Selain itu, JGG tidak menarik biaya dalam jasa tour nya, yang menyebabkan publik tertarik untuk mencoba mengikuti program JGG.

Sejak Tahun 2014, JGG sudah banyak mengenalkan daya tarik wisata Kota Tua, Jakarta ke para wisatawan mancanegara dan juga domestik. Wisatawan yang mengikuti walking tour ini setiap tahunnya semakin bertambah. Jumlah wisatawan yang mengikuti Walking Tour Kota Tua, Jakarta dari Tahun 2014 misalnya ada 200 wisatawan, Tahun 2015 diikuti 350 wisatwam, dan Tahun 2016 meningkat menjadi 600 wisatawan (Sumber : JakartaGoodGuide, 2016).

Dalam menjalankan profesinya, para anggota komunitas JGG tidak hanya asal dalam membawakan tour, tetapi mereka juga memperhatikan serta menerapkan beberapa strategi komunikasi dan juga metode komunikasi dalam membawakan tour di hadapan para klien. Beberapa metode yang digunakan, yaitu metode informatif, instruktif, dan juga metode persuasif. (Uripni, Sujianto \& Indrawati, 2003: 14).

Penelitian ini penting, karena diharapkan mampu mengkaji bagaimana strategi komunikasi suatu komunitas dalam meningkatkan awareness publik terhadap daya tarik wisata Kota Tua di Jakarta. Adapun tujuan penelitian ini untuk mengetahui strategi komunikasi apa yang digunakan komunitas JakartaGoodGuide untuk meningkatkan awareness publik terhadap daya tarik wisata Kota Tua, Jakarta. Selain itu, untuk mengetahui apa dampak dari strategi komunikasi yang digunakan dalam meningkatkan awareness 
publik mengenai daya tarik wisata Kota Tua, Jakarta

\section{KERANGKA KONSEP}

Istilah komunikasi yang dalam bahasa Inggris communication, berasal dari kata Latin, yaitu communicatio, dan bersumber dari kata communis yang berarti sama. Sama di sini maksudnya adalah sama makna. Menurut Hovland (dalam Effendy, 2006: 10) komunikasi adalah suatu upaya untuk merumuskan asas-asas penyampaian informasi serta pembentukan pendapat dan sikap.

Menurut Rogers dan D. Lawrence Kinciad (1981), dalam Cangara (2014: 36) mengatakan bahwa komunikasi adalah suatu proses dimana dua orang atau lebih membentuk atau melakukan pertukaran informasi dengan satu sama lainnya, yang pada gilirannya akan tiba pada saling pengertian yang mendalam. Dari definisi diatas, dapat disimpulkan bahwa komunikasi merupakan proses penyampaian pesan dari komunikator kepada komunikan dan bertujuan agar terdapat perubahan sikap serta tingkah laku seorang komunikan sesuai dengan yang diharapkan.

Terdapat 3 (tiga) metode komunikasi yang biasa digunakan saat berkomunikasi, yaitu metode persuasif, metode informatif, dan juga metode instruktif (Uripni, Sujianto \& Indrawati, 2003: 14). Metode persuasif merupakan metode komunikasi yang bersifat membujuk secara halus agar sasaran yang dituju merasa yakin, biasanya dilakukan dengan ajakan dengan beberapa alasan yang bersifat meyakinkan; metode informatif merupakan metode yang digunakan untuk menyampaikan informasi secara umum. Metode ini bersifat menerangkan, dan penerangan tersebut harus bersifat edukatif, persuasif, serta stimulatif; serta metode instruktif merupakan metode berupa arahan atau perintah untuk melakukan sesuatu tugas atau melakukan suatu pekerjaan.

Strategi adalah dasar dari serangkaian keputusan dan tindakan yang dibuat oleh kepala manajemen dan diterapkan oleh jajaran suatu organisasi dengan niatan agar tujuan organisasi dapat tercapai dengan baik (Siagian, 2008: 15).

Strategi komunikasi merupakan gabungan dari perencanaan komunikasi serta manajemen untuk mencapai suatu objektif. Untuk mencapai objektif, strategi komunikasi tidak hanya berfungsi sebagai penunjuk arah, tetapi harus dapat menunjukkan taktik operasionalnya yang dapat dilakukan. Dengan demikian, strategi komunikasi, baik secara makro (plammed multi-media strategi) maupun secara mikro (single communication medium strategi) mempunyai fungsi ganda (Effendy, 2008: 29), yaitu menyebarluaskan pesan komunikasi yang bersifat informatif, persuasif dan instruktif secara sistematik kepada sasaran untuk memperoleh hasil optimal; dan menjembatani "kesenjangan budaya" akibat kemudahan diperolehnya dan kemudahan dioperasionalkannya media massa yang sangat ampuh yang jika dibiarkan akan merusak nilai-nilai budaya. Untuk mengetahui strategi komunikasi apa yang digunakan oleh JGG untuk meningkatkan public awareness terhadap Kota Tua, Jakarta, maka peneliti menggunakan model komunikasi dari Lasswell (dalam Mulyana, 2011: 69), yang dimana model komunikasi ini menggunakan 5 pertanyaan yang harus ditanyakan dan dijawab dalam melihat proses komunikasi, yaitu Who says What in Which Channel To Whom With What Effect?

Model yang ditemukan oleh Harold Lasswell ini seringkali digunakan dalam komunikasi massa. Model tersebut mengisyaratkan bahwa lebih dari satu saluran yang dapat membawa pesan.

Unsur Sumber (who) mengundang pertanyaan mengenai pengendalian pesan, unsur Pesan (says what) merupakan bahan 
untuk analisis isi, Media komunikasi (in which channel) dikaji dalam analisis media, unsur Penerima (to whom) dikaitkan dengan analisis audiens, dan unsur Pengaruh (with what effect) berhubungan dengan studi mengenai pengaruh pesan kepada khalayak (Wiryanto, 2004: 17).

Menurut Ruslan (2007: 37), terdapat beberapa tujuan dari strategi komunikasi, diantaranya yaitu: 1) To Secure Understanding: untuk memastikan bahwa terjadi suatu pengertian dalam berkomunikasi, 2) To Establish Acceptance: bagaimana cara penerimaan komunikasi terus dibina dengan baik, 3) To Motivate Action: penggiatan untuk memotivasinya, dan 4) To Goals which the communicator sought to achieve: yaitu bagaimana cara mencapai tujuan yang diinginkan dari proses komunikasi tersebut.

Istilah public dalam Bahasa Indonesia adalah publik, yaitu sebagai suatu kelompok dalam masyarakat, yang dimana dalam masyarakat yang bersifat heterogen, terdapat sekelompok orang yang sifatnya homogen. Sifat homogen inilah yang disebut dengan "publik" (Yulianita, 2007: 17).

Grunig dan Todd Hunt berpendapat bahwa terdapat berbagai macam respon dari orang-orang yang berbeda ketika menghadapi suatu permasalahan. Beberapa orang akan mengabaikannya serta menjalankan masalah tersebut dan beberapa orang lainnya akan menyadari masalah tersebut dan memilih untuk tidak melakukan apa-apa. Kemudian, Grunig dan Hunt (dalam Butterick, 2013: 28-29). mendefinisikan 4 (empat) tipe publik, yaitu: 1) Non Public, organisasi tidak memiliki kepentingan terhadap kelompok, begitu juga kelompok tidak memiliki kepentingan terhadap organisasi, 2) Latent Public, kelompok menghadapi ancaman yang sama dari organisasi, namun mereka tidak dapat menemukan dimana letak permasalahannnya, 3) Aware Public, kelompok yang memahami adanya permasalahan bersama, dan 4) Active Public, kelompok yang menyadari adanya permasalahan, lalu mencoba untuk bekerjasama dan menentukan hal apa yang akan dilakukan untuk menyelesaikan permasalahan tersebut.

Publik yang dituju oleh JGG sendiri ialah wisatawan domestik dan wisatawan mancanegara. Peneliti memilih wisatawan domestik sebagai tujuan publik dari JGG karena mereka hanya sekedar mengetahui Kota Tua, tetapi tidak mengetahui asalusul dan sejarah objek wisata tersebut. Bahkan, banyak wisatawan yang hanya mengambil foto di kawasan Kota Tua tanpa tertarik untuk masuk dan mengetahui lebih lanjut mengenai berbagai museum di kawasan itu, sehingga peneliti berharap strategi komunikasi yang disampaikan dapat diterima dengan baik oleh publik tersebut. Di sisi lain, banyak wisatawan mancanegara yang masih belum mengenal Kota Tua karena kurang publikasi dibandingkan dengan daya tarik wisata lainnya seperti Ancol dan Taman Mini. Mereka juga umumnya tidak tahu harus bertanya kemana dan pada siapa mengenai daya tarik wisata tersebut, karena orangorang yang berada di sekitar Kota Tua belum tentu tahu betul mengenai sejarah dan asal-usul Kota Tua.

$\begin{array}{lrr}\text { Awareness } & \text { (kesadaran) } & \text { adalah } \\ \text { mempromosikan } & \text { kredibilitas } & \text { serta }\end{array}$ visibilitas dalam komunitas atau masyarakat. Awareness digunakan untuk memberikan informasi serta mendidik seseorang mengenai topik ataupun isu dengan tujuan untuk mempengaruhi sikap, perilaku dan keyakinan terhadap pencapaian untuk menentukan tujuan yang ingin dicapai (Sayers, 2006: 10).

Daya tarik wisata adalah segala sesuatu yang memiliki keunikan, keindahan, dan nilai yang berupa keanekaragaman kekayaan alam, budaya, dan hasil buatan manusia yang menjadi sasaran atau tujuan kunjungan wisatawan (Undang Undang Republik Indonesia Nomor 10 tahun 
2009). Menurut Yoeti (2006: 164 ) menyatakan bahwa, daya tarik wisata adalah segala sesuatu yang menjadi daya tarik bagi wisatawan untuk mengunjungi suatu daerah tertentu. Pada dasarnya secara garis besar data tarik wisata dapat dibagi menjadi 2 (dua) kelompok, yakni daya tarik wisata alam dan daya tarik wisata budaya. Daya tarik wisata alam adalah daya tarik ciptaaan Tuhan Yang Maha Esa yang antara lain terdiri dari keindahan alam, flora fauna, hutan, gunung, sungai, laut, goa, dan cuaca, sedangkan daya tarik wisata budaya merupakan hasil cipta, rasa, karsa, dan karya manusia antara lain terdiri dari museum, bangunan, atraksi, peninggalan seni, sejarah, taman rekreasi, dan hiburan.

\section{METODE PENELITIAN}

Pada penelitian ini peneliti menggunakan metode deskriptif dengan pendekatan kualitatif. Salah satu karakterisktik penelitian kualitatif adalah deskriptif dimana data yang dikumpulkan berupa kata-kata, gambar, dan bukan angka karena menerapkan metode kualitatif. Semua data yang dikumpulkan berkemungkinan menjadi kunci terhadap apa yang diteliti. Melalui metode penelitian ini, peneliti akan memberikan gambaran terhadap keadaan serta fenomena suatu objek yang diteliti secara mendalam dengan melakukan wawancara.

Metode penelitian deskriptif kualitatif termasuk metode baru, karena popularitasnya belum lama. Metode penelitian kualitatif sering disebut juga sebagai metode penelitian naturalistik, karena penelitiannya bersifat alamiah. Sebelumnya metode ini sering digunakan untuk penelitian di bidang antropologi budaya, sehingga disebut sebagai metode etnografi.

Penelitian ini dilakukan pada objek yang alamiah, dimana tidak direkayasa ataupun dimanipulasi oleh peneliti sendiri, dan kehadiran peneliti juga tidak mempengaruhi dinamika pada objek tersebut. Objek dalam penelitian ini yaitu komunitas JakartaGoodGuide dengan memfokuskan kepada strategi komunikasi JGG dalam meningkatkan awareness di mata publik mengenai daya tarik wisata Kota Tua, Jakarta.

Teknik pengumpulan data pada penelitian ini dengan melakukan wawancara, observasi, dan mengumpulkan data dokumentasi di lapangan, Sumber data diambil dari jenis data primer dan data sekunder yang dikumpulkan. Pengumpulan data dilakukan pada sumber data primer dan sekunder dari bulan SeptemberDesember 2016. Data primer disini adalah data yang diperoleh peneliti secara langsung dari narasumber sebagai informan yang berhubungan dengan fokus penelitian, sedangkan data sekunder adalah data yang telah dikumpulakn oleh pihak lain, bukan oleh peneliti sendiri untuk tujuan lain, sehingga peneliti hanya sekedar mencatat, mengakses, atau meminta data tersebut ke pihak lain yang telah mengumpulkannya di lapangan (Istijanto, 2009).

Guna mendapatkan data informasi yang akurat, maka dalam penelitian ini peneliti memilih informan yang dianggap mampu memberikan jawaban atas permasalahan penelitian. Oleh karena itu, peneliti mewawancarai 3 orang informan dalam penelitian ini yaitu: 1) Founder JakartaGoodGuide, 2) Senior tour guide dari JakartaGoodGuide, dan 3) customer JakartaGoodGuide,

Dalam Penelitian ini, peneliti menggunakan analisis data kualitatif dan analisis data model Miles dan Huberman. Analisis data pada metode ini dilakukan pada saat berlangsungnya pengumpulan data, dan pada saat selesai pengumpulan data di periode tertentu. Pada saat wawancara, peneliti sudah mulai menganalisis jawaban yang dilontarkan oleh narasumber. Jika jawaban narasumber kurang memuaskan, maka peneliti tetap akan memberikan pertanyaan kembali 
sampai pada tahap tertentu dimana peneliti mendapatkan jawaban yang kredibel dari narasumber (Sugiyono, 2013: 246).

Miles dan Huberman mengemukakan bahwa aktivitas dalam analisis data kualitatif dilakukan secara interaktif dan berlangsung secara terus menerus sampai tuntas, sehingga datanya sudah jenuh. Aktivitas dalam analisis data menurut Miles dan Huberman, yaitu data reduksi, data display, conclucion drawing/verification. Setelah peneliti mengumpulkan data, maka peneliti melakukan anticipatory sebelum melakukan reduksi data. Anticipatory adalah penelitian yang memutuskan kerangka konseptual mana yang dipilih (Sugiyono, 2013: 246).

\section{HASIL DAN PEMBAHASAN}

\section{Hasil Penelitian}

Kota Tua merupakan salah satu daya tarik wisata budaya berupa peninggalan bangunan bersejarah yang sampai saat ini masih dijaga kekhasannya. Beberapa bagunan tua tersebut dapat digunakan dengan baik, seperti misalnya Stasiun Jakarta Kota dan Kantor Pos Indonesia. Bangunan tua lainnya dijadikan museum agar wisatawan dapat menengetahui sejarah pada saat pemerintahan Belanda. Museum yang terdapat di kawasan Kota Tua antara lain yaitu Museum Wayang, Museum Keramik, Museum Bank Indonesia, Museum Bank Mandiri, dan Museum Fatahilah. Namun dari antara museum di atas, museum yang cukup digemari wisatawan adalah Museum Fatahilah. Alasannya, karena museum tersebut merupakan museum sejarah Jakarta yang di dalamnya terdapat banyak sekali benda koleksi peninggalan Belanda. Menariknya, di dalam museum tersebut terdapat ruangan tersembunyi yang membuat penasaran wisatawan, dan sangat bagus jika diabadikan melalui foto. Ruangan tersebut misalnya, ruangan prasejarah Jakarta, penjara bawah tanah, dan juga sumur pada saat masa pemerintahan Belanda.

JakartaGoodGuide (JGG) adalah salah satu komunitas yang terdiri dari anak-anak muda yang memiliki kemampuan untuk membawakan tour dengan berbekal bahasa Inggris yang baik, dan berlisensi dari Dinas Pariwisata DKI Jakarta. Mereka menawarkan jasa tourguide di Jakarta dengan beberapa rute seperti Old Town, China Town, Cikini, Monas, Menteng, Jatinegara, dan Pasar Baru. JakartaGoodGuide sendiri dikenal dengan julukan "Pay as You Wish" Tour.

JGG berdiri Tahun 2014, berawal dari salah satu anggota tourguide memiliki ide untuk membuat komunitas seperti di luar negeri yang biasa dikenal dengan nama free walking tour, karena di Jakarta belum ada. Namun, masyarakat Indonesia belum terbiasa dengan "free walking tour", karena mereka benar-benar tidak memberikan biaya pengganti transportasi kepada anggota JGG sama sekali. Kemudian, JGG memberi julukan lain yaitu "pay as you wish" dengan harapan peserta bebas memberikan tips atau sebagai pengganti biaya transportasi.

Visi JGG adalah berusaha menjadikan Jakarta sebagai salah satu kota yang menarik untuk dijelajahi oleh wisatawan. Untuk mewujudkan Visi tersebut, JGG mengemban misi, yaitu: 1) Mengadakan program Jakarta walking tour rutin dengan sistem membayar sesuai kepuasan (pay as you wish) agar semua orang dari berbagai kalangan bisa mengikutinya, 2) Menjelajahi satu tempat baru yang memiliki nilai sejarah atau budaya dengan berjalan kaki, 3) Membuat tour-tour tematik seperti tour ke museum atau tour menjelajahi tempat-tempat yang berhubungan dengan tokoh sejarah seperti Chairil Anwar, Sukarno, dan lainnya, 4) Menyediakan servis pemandu wisata untuk turis mancanegara atau domestik untuk membantu mereka menjelajahi Jakarta, 5) Menyediakan jasa pembuatan rencana perjalanan wisata bagi turis mancanegara 
atau domestik yang ingin berwisata di Jakarta, dan 6) Bekerja sama dengan komunitas-komunitas yang ada untuk melakukan kegiatan bersama yang bersifat penjelajahan kota Jakarta yang bersifat edukasi dan menghibur. Adapun, tujuan utama dari komunitas ini yaitu untuk menjadikan Jakarta sebagai Kota yang ramah dengan wisatawan.

Pada saat ini, JGG memiliki beberapa media sosial aktif yang dapat diakses oleh para wisatawan. Awalnya JGG hanya memiliki blog aktif yang dapat dibaca oleh para pengguna internet. Namun seiring berjalannya waktu, JGG membuat media sosial lain guna menyebarkan informasi lebih luas mengenai komunitas mereka, sehingga media yang dimilikii sekarang adalah Blog, Instagram, Twitter, dan Facebook. Dalam media sosialnya, JGG memuat jadwal-jadwal walking tour selama sebulan, cerita mengenai walking tour yang sudah berjalan, foto-foto dokumentasi menarik dari berbagai rute, dan tentunya juga testimonial dari para partisipan. Selain itu, para calon partisipan dapat dengan mudah mendaftarkan diri mereka untuk mengikuti walking tour melalui blog JakartaGoodGuide

Setiap organisasi termasuk komunitas membutuhkan strategi komunikasi yang baik untuk mengkomunikasikan pesanpesan yang akan disampaikan kepada pubilknya. Demikian juga dengan JGG memerlukan strategi komunikasi yang baik guna menarik perhatian wisatawan yang mengikuti walking tour agar dapat mengerti isi pesan yang disampaikan mengenai sejarah dan asal-usul Kota Tua. Tujuan akhirnya untuk meningkatkan awareness di mata publik mengenai daya tarik wisata Kota Tua, Jakarta terutama kepada para wisatawan .

Berdasarkan hasil penelitian terdapat 4 (empat) strategi komunikasi yang digunakan oleh JGG dalam meningkatkan awareness publik mengenai daya tarik wisata Kota Tua, Jakarta sebagai berikut :
Strategi pertama adalah berkomunikasi secara persuasif.. Tim tourguide JGG menggunakan komunikasi persuasif dengan bahasa sehari-hari yang santai dan tidak formal, namun sopan sehingga dapat menarik perhatian, pesan yang disampaikan dapat dengan mudah diterima dan dimengerti oleh wisatawan. Strategi ini bertujuan agar peserta dapat melakukan tanya jawab dengan santai, dan tidak ada gap antara tim JGG dengan wisatawan. Seperti yang diungkapkan oleh Mas Candha:

"Kami membuat sebagai teman mereka, tidak hanya searah atau dua arah. Apapun dapat diceritakan, kami mendengarkan pertanyaan maupun cerita dari para wisatawan tersebut, sehingga mereka merasa nyaman selama berjalan bersama kami. Dan tentunya dengan komunikasi yang santai dan nyaman, maka dapat dengan mudah pesan yang disampaikan oleh tim kami diterima baik dan dimengerti oleh para partisipan sehingga pengetahuan mengenai Kota Tua sendiri akan tercipta." Strategi kedua, adalah menggunakan katakata ringan yang mudah diingat, mengajukan pertnyaan yang membuat para peserta aktif sehingga dapat mengingat momen yang ada pada saat itu, dan kadang-kadang menggunakan lelucon yang tidak menyinggung SARA, sesuai dengan apa yang dikatakan oleh Mas Farid :

"Pemandu harus memilih kata-kata yang ringan, mudah dimengerti, dan bersifat sehari-hari; kemudian mengeluarkan triviatrivia simple tapi menarik untuk peserta, lalu mengajukan pertanyaan yang membuat peserta mengingat dan berperan aktif di dalam grup; kemudian boleh sesekali mengeluarkan lelucon yang tidak bersifat SARA atau menyinggung peserta”. Strategi ketiga yang digunakan adalah menyampaikan pesan secara terstruktur sehingga pesan yang disampaikan oleh tim JGG mudah dimengerti dan diingat oleh wisatawan; Proses penyampaian pesan sangat detail dan tentunya berurut dari awal berdirinya suatu bangunan, kejadian 
apa saja yang terjadi di tempat tersebut pada masa penjajahan Belanda, hingga keberadaan bangunan pada saat ini.

Strategi komunikasi keempat adalah dengan menggunakan gambar atau foto sebagai alat peraga dalam suatu tour. Hal ini diterapkan guna membuat para wisatawan mudah mengingat cerita asalusul dari suatu bangunan dan juga untuk membantu peserta agar dapat membayangkan kondisi dari satu tempat bersejarah tersebut, seperti yang dikatakan oleh Mas Farid :

"Kami juga kadang menggunakan gambar untuk membantu peserta membayangkan setting cerita atau kondisi dari satu tempat yang menjadi titik cerita si pemandu."

Strategi yang dibentuk oleh JakartaGoodGuide sesuai dengan tujuan dari strategi komunikasi yang dituturkan oleh Ruslan (2007: 37), yaitu : 1) To Secure Understanding: yaitu untuk memastikan bahwa terjadi suatu pengertian dalam berkomunikasi. Dalam melakukan penyampaian pesan, Tim JGG melakukan komunikasi secara terstruktur sehingga pesan yang disampaikan dapat mudah dipahami sesuai dengan alur kejadian sejara objek wisata tersebut;; 2) To Establish Acceptance: yaitu bagaimana cara penerimaan komunikasi terus dibina dengan baik. Tim JGG melalukan komunikasi secara persuasif, dengan cara menggunakan bahasa sehari-hari agar peserta lebih nyaman dengan keberadaan Tim JGG sendiri; 3) To Motivate Action: yaitu penggiatan untuk memotivasinya. Dengan adanya JGG, wisatawan baik lokal maupun mancanegara tentunya lebih tertarik untuk mengunjungi objek wisata Kota Tua, karena akan ada yang menjelaskan asal-usul sejarah objek wisata secara runtut; 4) To Goals which the communicator sought to achieve: yaitu bagaimana cara mencapai tujuan yang diinginkan dari proses komunikasi tersebut. Dengan menggunakan alat bantu seperti gambar ataupun foto, Tim JGG dapat dengan mudah mencapai tujuan mereka, yaitu membuat Jakarta ramah akan turis dan juga memperkenalkan Objek wisata Kota Tua kepada wis wisatawan terutama wisatawan mancanegara.

Pertanyaan yang terdapat dalam model komunikasi lasswell, dimana dalam suatu proses komunikasi, diperlukan jawaban untuk menjawab 5 pertanyaan berikut, yaitu Who says What in Which Channel To Whom with What Effect. Hal ini sesuai dengan apa yang diungkapkan oleh Mas Farid :

"Pada saat berjalannya walking tour, guide kami akan menceritakan kepada para partisipan mengenai asal-usul tempat sejarah yang akan kami tuju dengan menggunakan mic sehingga partisipan dapat dengan jelas mendengarkan penjelasan dari kami. Dari pengalaman kami selama ini, pada saat menceritakan sejarah dan juga asal-usul, partisipan mendengarkan dengan seksama dan dengan spontanitas mereka akan bertanya lebih dalam tentang apa yang belum mereka ketahui."

Penerapan dari strategi komunikasi yang telah direncanakan oleh tim JGG dapat menimbulkan dampak bagi para wisatawan yang mengikuti walking tour. Hal ini menjadi salah satu kunci penting yang harus diketahui oleh tim JGG agar dapat merubah strategi komunikasi mereka jika dampak yang diterima oleh pihak eksternal negatif, dan juga mempertahankan strategi komunikasi tersebut jika dampak yang diterima oleh para partisipan positif.

Hal pertama yang peneliti tanyakan kepada partisipan yang diwawancarai adalah mengenai pesan yang disampaikan oleh tim JGG. Apakah pesan yang disampaikan oleh pihak JGG dapat diterima dengan jelas oleh wisatawan, Ibu Juni dari pihak eksternal mengungkapkan :

"Ya, pesan yang disampaikan dapat dengan mudah dimengerti, karena mereka menggunakan bahasa yang santai dan tidak berat sehingga pesan yang disampaikan langsung bisa diterima karena perjalanan bersama mereka tidak tegang, sehingga 
kami pun dapat dengan leluasa bertanya jika belum mengerti. Selain itu juga materi yang disampaikan sangat ringkas, jadi kami mudah untuk mengingatnya."

Pada proses komunikasi ini, dampak yang diterima oleh para partisipan yaitu dampak kognitif, dimana para partisipan menjadi tahu mengenai asal-usul Kota Tua, dan juga menambah informasi baru yang selama ini belum diketahui oleh para partisipan. Selain itu juga pesan yang disampaikan oleh komunikator dapat diterima dengan baik dan dapat mengubah persepsi Kota Tua, yang sebelumnya mereka pikir hanya berupa bangunan angker.

JGG yang dikenal sebagai trendsetter walking tour di Jakarta dinilai dapat memposisikan diri mereka di posisi wisatawan, dimana mereka memikirkan cara apa yang tepat untuk dapat membuat wisatawan nyaman pada saat walking tour bersama dengan mereka. Sehingga mereka harus mengerti strategi komunikasi apa yang cocok untuk diberlakukan pada saat walking tour, agar pihak eksternal yang mengikuti jasa mereka merasa nyaman dan dapat menerima pesan yang ingin disampaikan dengan baik.

Ketika peneliti menanyakan hal lain kepada pihak eksternal, yaitu mengenai awareness di mata para peserta tour, apakah partisipan merasa adanya peningkatan awareness mengenai daya tarik wisata Kota Tua, Jakarta, atau tidak. Peneliti menanyakan hal tersebut karena hal tersebut merupakan salah satu tujuan dari strategi yang dijalankan oleh JGG, Bapak Deni yang sudah lebih dari sekali mengikuti walking tour ini mengungkapkan bahwa:

"Ya, tentunya. Setelah mengikuti walking tour ini, aku jadi tau lebih banyak mengenai asal-usul objek wisata Kota Tua sendiri. Karena dari dulu sejak sekolah, hanya tahu mengenai sejarah yang memang ada di buku pelajaran saja."

Tidak hanya itu, peneliti juga menanyakan apakah masih ada yang kurang dari pembawaan tour itu sendiri. Karena dalam menjalankan suatu jasa, pasti ada rasa kurang puas yang dirasakan oleh partisipan sendiri. Ibu Juni mengungkapkan bahwa :

"Menurutku secara keseluruhan sudah baik, bahasanya sudah baik, baik bahasa Inggris maupun bahasa Indonesia nya, namun terkadang penjelasan yang disampaikan agak terlalu cepat, sehingga aku perlu memutar otak agar dapat mengerti jalan ceritanya, mungkin karena waktu perjalanannya terbatas."

Hal lain diungkapkan oleh Bapak Deni :

"Yang saya rasa kurang hanyalah waktu perjalanannya saja, karena kita mengunjungi beberapa tempat bersejarah, dan ditempat tersebut pasti ada sesi fotofoto, maka waktu 2 jam saya rasa kurang untuk menelusuri daerah Kota Tua tersebut."

Menurut Ibu Juni dan Bapak Deni, JGG merupakan pioneer dari walking tour. Mereka merasa terbantu dengan keberadaan JGG saat ini, karena jika tidak ada JGG, mereka meyakini bahwa mereka pasti malas dan tidak akan berwisata ke Kota Tua, Jakarta. Jika mereka tidak menggunakan jasa tour guide, mereka hanya akan mengabadikan foto di bangunan-bangunan tua, tanpa mengerti asal-usul dan sejarah dari Kota Tua itu sendiri. Mereka juga tidak mengetahui letak pasti dari objek wisata yang tidak familiar, dan rute-rute kendaraan menuju objek wisata satu dengan yang lainnya karena jarak yang cukup jauh seperti misalnya dari Kota Tua ke Pelabuhan Sunda Kelapa.

Setelah mengikuti walking tour dengan rute Kota Tua, mereka mengaku bahwa merasa penasaran dengan rute-rute lainnya yang dimiliki oleh JGG seperti Monas dan juga Chinatown, dan mereka mengatakan akan mengikuti rute tersebut terutama rute khusus dengan objek wisata berbeda yang diadakan setiap bulan nya. Selain untuk menambah informasi dan pengetahuan mengenai sejarah Kota Jakarta, mereka juga merasa dengan mengikuti walking 
tour bersama dengan JGG, mereka memiliki banyak teman baru baik teman yang berada di dalam negeri maupun luar negeri.

Hal ini terbentuk karena strategi komunikasi yang disampaikan oleh tim JGG sesuai dengan target dan telah diterima dengan baik dan oleh para partisipan berkat strategi komunikasi yang dibentuk oleh JGG, sehingga para partisipan mengerti apa yang disampaikan oleh tim JGG yang membawakan tour dan mau mengulangi perjalanan bersama dengan JGG.

\section{Pembahasan}

Berdasarkan analisis di atas, hasil penelitian menunjukkan bahwa strategi komunikasi merupakan suatu elemen penting yang harus diperhatikan oleh pihak internal suatu organisasi atau perusahaan. Strategi yang dibutuhkan yaitu strategi yang baik, dimana strategi tersebut dapat diterima oleh publik sesuai target komunitas dan tentunya dapat menarik perhatian publik sehingga strategi yang telah direncanakan dapat terlaksana dengan baik untuk mencapai tujuan dari komunitas tersebut.

Berdasarkan temuan peneliti yang mengacu pada konsep komunikasi yang digambarkan oleh Harold Lasswell "Who Says What In Which Channel To Whom With What Effect", maka dapat dijabarkan proses komunikasi yang dilakukan oleh JGG.

Sumber adalah suatu pihak yang memiliki kebutuhan berkomunikasi untuk menyampaikan informasi tertentu. Dalam penelitian ini, JGG diposisikan sebagai sumber yang akan menyampaikan pesan ke dalam seperangkat simbol agar pesan tersebut dapat diterima dengan baik oleh penerima (publik).

Kedua, pesan, yaitu hal yang ingin disampaikan oleh sender kepada receiver. Simbol tersebut dapat berupa simbol verbal dan juga non verbal. Pesan yang ingin disampaikan oleh JGG sendiri yaitu bahwa tempat wisata yang ada di Jakarta tidak hanya Ancol dan Taman Mini saja, melainkan ada banyak tempat bersejarah yang bisa dikunjungi oleh para wisatawan. Ketiga adalah Media, dimana berfungsi sebagai penyalur penyampaian pesan dari sender kepada receiver. tujuannya adakah agar pesan yang ingin disampaikan dapat tercerna dengan baik oleh receiver. JakartaGoodGuide menyampaikan pesannya menggunakan microphone untuk membantu memperbesar suara pemandu agar dapat terdengar dengan jelas oleh para peserta.

Keempat adalah penerima (receiver), yaitu orang yang menerima pesan dari sender, yang dapat mencerna simbol verbal ataupun nonverbal yang akan menjadi suatu gagasan yang ia pahami. Penerima pesan dari JGG ini adalah wisatawan asing ataupun lokal yang mengikuti program Pay as You Wish Walking Tour.

Kelima adalah efek, yang dimaksud dengan efek disini adalah hal apa yang terjadi setelah pesan yang dikirim oleh sumber diterima oleh penerima pesan. Pada proses komunikasi JakartaGoodGuide, efek yang dirasakan yaitu wisatawan menjadi aware mengenai objek wisata Kota Tua, Jakarta.

Dari teori Harold Lasswell tersebut, dapat digambarkan bahwa JGG yang adalah sumber pesan, tentunya harus dapat memformulasikan symbol-simbol dalam bentuk verbal ataupun non verbal melalui media yang sesuai dengan yang dibutuhkan oleh JGG sendiri, sehingga pada pikiran si penerima pesan, dapat timbul pemikiran yang sama dengan apa yang ingin disampaikan oleh JakartaGoodGuide sendiri. Dan tentunya pesan yang disampaikan tersebut dapat memberikan pengaruh kepada penerima pesan, yaitu berupa awareness mengenai daya tarik wisata Kota Tua, Jakarta.

JakartaGoodGuide memilih microphone sebagai media pada saat penyampaian pesan karena media tersebut termasuk 
media yang efektif dan efisien yang dapat memberikan pengaruh kepada banyak orang dalam waktu yang bersamaan. Tim JGG memikirkan hal ini karena menurut mereka, jika tidak menggunakan microphone, para peserta tidak akan dapat mendengar isi pesan yang disampaikan oleh tim JGG, dikarenakan jumlah peserta per grup yang mengikuti tour tersebut lebih dari 5 orang, dan juga mereka melakukan perjalanan di tempat terbuka sehingga banyak sekali gangguan-gangguan yang didapat dari luar, seperti misalnya suara bising kendaraan, pengunjung Kota Tua diluar peserta walking tour JGG, serta penjual di kawasan Kota Tua yang menawarkan barang dagangan mereka kepada para pengunjung.

\section{SIMPULAN DAN SARAN}

Simpulan

Berdasarkan hasil penelitian dan pembahasan mengenai "Strategi Komunikasi JakartaGoodGuide dalam Meningkatkan Awareness Publik terhadap Daya Tarik Wisata Kota Tua, Jakarta", maka peneliti menarik kesimpulan sebagai berikut:

Pengetahuan wisatawan yang menggunakan jasa JakartaGoodGuide meningkat berkat strategi komunikasi yang telah dilakukan oleh JakartaGoodGuide. Wisatawan menjadi lebih dalam mengetahui asal-usul dan sejarah dari daya tarik wisata Kota Tua.

Strategi yang digunakan oleh JakartaGoodGuide untuk meningkatkan awareness mengenai daya tarrik wisata Kota Tua sendiri adalah dengan 4 (empat) cara, yakni: 1) Menggunakan komunikasi yang persuasif sehingga wisatawan merasa nyaman pada saat kegiatan berlangsung, tanpa adanya gap antara tour guide dengan wisatawan; 2) Mengemas komunikasi dengan cara, memilih kata-kata yang ringan pada saat penyampaian pesan agar pesan dapat diterima oleh semua kalangan; mengajukan pertanyaan yang membuat para peserta berperan aktif. dan sesekali mengeluarkan lelucon yang tidak mengandung SARA; 3) Menyampaikan pesan secara terstruktur sehingga pesan yang disampaikan oleh tim mudah dimengerti dan diingat oleh partisipan;, 4) Menggunakan alat bantu berupa foto atau gambar agar wisatawan dapat membayangkan dan merasakan suasana pada masa tersebut, dan agar dapat lebih mudah mengingat cerita asal-usul kejadian bersejarah tersebut.

Terdapat sebuah hambatan yang signifikan yang dihadapi oleh JGG dalam menjalankan proses komunikasi. Hambatan yang dihadapi yaitu ketika terdapat perbedaan bahasa dalam satu grup, dimana ada wisatawan lokal yang tidak dapat berbahasa Inggris, dan ada wisatawan asing yang juga tidak dapat berbahasa Indonesia. Dalam mengatasi hambatan tersebut, tim JGG menggunakan dua bahasa yang berarti penjelasan diusahakan sejelas dan sesingkat mungkin karena adanya penambahan durasi untuk tur bilingual. Dan terkadang yang mereka lakukan adalah melakukan pemanduan menjadi satu bahasa yang dominan dipakai lalu penjelasan kepada peserta yang berbahasa lain dilakukan sambil jalan menuju ke titik lainnya.

\section{Saran}

Berdasarkan simpulan di atas, penulis memberikan saran sebagai berikut:

Penelitian berikutnya diharapkan dapat menggali lebih dalam mengenai strategi yang digunakan oleh JakartaGoodGuide, tidak hanya strategi komunikasi, melainkan kuga terhadap tingkat kepuasan wisatawan. JakartaGoodGuide diharapkan mempertahankan dan meningkatkan strategi yang telah digunakan saat ini agar pesan yang tersampaikan terus dapat diterima dengan baik oleh wisatawan guna meningkatkan awareness publik mengenai daya tarik Kota Tua, Jakarta,

\section{DAFTAR PUSTAKA}


Ardianto, E. (2014). Metodologi Penelitian untik Public Relations Kuantitatif dan Kualitatif. Bandung: Simbiosa Rekatama Media

Bajari, A. (2015). Metode Penelitian Komunikasi Prosedur, Tren, dan Etika. Bandung: Simbiosa Rekatama Media.

Bowden, D. 2014. Happening Jakarta. Jakarta, Indonesia: Jakarta City Government Tourism and Culture Office.

Bungin, B. 2009. Metodologi Penelitian Kualitatif. Jakarta: Kencana

Butterick, K. 2013. Pengantar Public Relations: Teori dan Praktik. Jakarta: PT RajaGrafindo Persada.

Cangara, H. 2014. Pengantar Ilmu Komunikasi. Jakarta: PT RajaGrafindo Persada.

Effendy, O. U. 2006. Dinamika Komunikasi. Cetakan keduapuluh, Bandung: PT Remaja Rosdakarya.

Effendy, O. U. 2008. Ilmu Komunikasi Teori dan Praktek. Bandung: PT Remaja Rosdakarya.

Istijanto. 2009. Aplikasi Praktis Riset Pemasaran. Jakarta: PT Gramedia Pustaka Utama.

JakartaGoodGuide. 2014. Community Profile [Handout]. Jakarta, Indonesia: JakartaGoodGuide.

Jakarta Walking Tour. [n.d.]. https://www.tripadvisor.com/Attraction_R eview-g294229-d7118308-ReviewsJakarta_Walking_Tour-Jakarta_Java.html Pricilla, M. 2015. Strategi Komunikasi Riau Tourism Board dalam Mempromosikan Pariwisata di Provinsi Riau.

http://id.portalgaruda.org/?ref=browse\&mo $\mathrm{d}=$ viewarticle \&article $=294914$

Mukhtar, P.D. 2013. Metode Praktis Penelitian Deskriptif Kualitatif (Pertama ed.). Jakarta: GP Press Group.

Mulyana, D. 2011. Ilmu Komunikasi Suatu Pengantar. Bandung: PT Remaja Rosdakarya.
Nurjaman \& Umam 2012. Komunikasi \& Public Relation. Bandung: CV Pustaka Setia.

Prigusnanto, I. 2006. Komunikasi Pemasaran : Strategi dan Taktik. Ciawi Bogor: Ghalia Indonesia.

Ruslan, R. 2007. Kiat dan Strategi Kampanye Public Relations. Jakarta: PT RajaGrafindo Persada.

Sayers, R. 2006. Principles of Awareness Raising. Bangkok: Communication and Information

Siagian, S.P. 2008. Manajemen Stratejik. Jakarta: Bumi Aksara.

Sugiyono. 2013. Metode Penelitian Kuantitatif, Kualitatif, dan R\&D. Jakarta: CV Alfabeta.

Sutaryo. 2005. Sosiologi Komunikasi. Yogyakarta: Arti Bumi Intaran.

Team, J. 2015. Kota Tua Jakarta. Diperoleh dari http://wisatajawa.co.id/tag/fasilitas-kotatua-jakarta/

TheGoodGuide 2016. Jumlah Wisatawan Yang Mengikuti Walking Tour Kota Tua Jakarta.

http://jakartagoodguide.wordpress.com/pag e/6/

Uripni, Sujianto \& Indrawati 2003. Komunikasi Kebidanan. Jakarta: Penerbit Buku Kedokteran EGC.

Wiryanto 2004. Pengantar Ilmu Komunikasi. Jakarta: PT Grasindo.

Yulianita, N. 2007. Dasar-Dasar Public Relations. Bandung: Pusat Penerbitan Universitas. 